\title{
Hukum dan Studi Penelitian Empiris: Penggunaan Metode Survey sebagai Instrumen Penelitian Hukum Empiris
}

\author{
F.C. Susila Adiyanta \\ Bagian Hukum Administrasi Negara, \\ Fakultas Hukum Universitas Diponegoro \\ susilafhundip@gmail.com
}

\begin{abstract}
In legal research, one of the instruments for collecting data and legal materials is the survey method. Often researchers in the field of legal science see surveys as a means to collect data from informants or research informants to conduct observations and interviews on an empirical approach (non-doctrinal legal research). This understanding is a form of simplification of survey methods as a research instrument that is complex and comprehensive. Research surveys were developed as a form of positivist approach to the social sciences. The conclusion of this research is the same as the study of social sciences, in the study of law, research is a building of logic, which from beginning to end must be a series of mutually explain each other. A legal research using scientific steps and stages which is systematic, logical and rational, makes the whole process of scientific writing as an explanation of logical logic which is a dialectical process between theory and data. In legal research, survey methods are used to evaluate various policies and decisions, and the implications of regulations on the community. The survey results can also be used to make predictions about a particular social phenomenon, including the application of positive law in the context of social and state social life.
\end{abstract}

Keywords: Survey Method, Legal Research

\begin{abstract}
Abstrak
Di dalam penelitian hukum, salah satu instrumen untuk mengumpulkan data dan bahan-bahan hukum adalah metode survey. Seringkali peneliti dibidang ilmu hukum melihat survey sebagai sarana untuk mengumpulkan data dari nara sumber atau informan penelitian untuk melakukan pengamatan dan wawancara pada pendekatan empiris (penelitian hukum non doktrinal). Pemahaman tersebut merupakan bentuk penyederhanaan metode survey sebagai instrumen penelitian yang bersifat kompleks dan komprehensif. Survey riset dikembangkan sebagai bentuk pendekatan positivis pada ilmu-ilmu sosial. Kesimpulan penelitian ini sama halnya dengan studi ilmu-ilmu sosial, dalam studi ilmu hukum, penelitian adalah suatu bangunan logika, yang dari awal sampai akhir harus merupakan rangkaian yang saling menjelaskan satu sama lain. Suatu penelitian hukum dengan menggunakan langkah-langkah dan tahapan ilmiah yang sistematis, logis dan rasional, menjadikan seluruh proses penulisan ilmiah sebagai suatu penjelasan logika pemikiran yang merupakan proses dialektikan antara teori dan data. Pada penelitian hukum, metode survey dimanfaatkan untuk melakukan evaluasi berbagai kebijakan dan keputusan, dan implikasi regulasi pada masyarakat. Hasil survey juga dapat digunakan untuk mengadakan prediksi mengenai suatu fenomena sosial tertentu, termasuk didalamnya adalah berlakunya hukum positif dalam konteks kehidupan sosial kemasyarakatan dan bernegara.
\end{abstract}

Kata Kunci: Metode Survey, Penelitian Hukum 


\section{A. Pendahuluan}

Studi tentang disiplin Ilmu Hukum secara ideal berpijak pada perspektif epistemologi beserta konsekuensi metodologisnya, bagaimana kedudukan aliran teori pemikiran hukum dalam paradigma keilmuan dan meta metodologi, namun hal tersebut seringkali diabaikan atau bahkan tidak tersentuh sama sekali. Sebagai konsekuensinya mahasiswa hukum kurang diajak untuk memahami cara berpikir akademik (academic, scientific thinking) agar mampu membangun logika berpikir yang dituangkan dalam penulisan artikel maupun karya ilmiah.

Dengan melihat secara acak beberapa karya ilmiah dan artikel yang ditulis penstudi Ilmu hukum, baik di tingkat sarjana, magister maupun doktoral di diunggah maupun yang menjadi koleksi dan arsip perpustakaan-perpustakaan fakultas hukum di Indonesia, terdapat format yang hampir seragam khususnya pada bagian metodologi atau metode penelitian, bahkan dengan susunan kalimat yang serupa. Misalnya selalu saja dapat dijumpai kalimat seperti ini “...pada penelitian ini menggunaka metode pendekatan....dengan spesifikasi penelitian, yang diikuti dengan penjelasan tentang apa itu spesifikasi penelitian, metode pendekatan..", tanpa memberi deskripsi lebih lanjut alasan, pertimbangan dan tujuan pemilihan maupun penggunaannya untuk penelitian yang akan dilakukan terkait dengan obyek penelitian ${ }^{1}$.

Begitu pula seringkali dijumpai format kalimat yang menyebutkan: “... dalam penelitian ini digunakan data primair, sekunder, tersier" serta diuraikan masing-masing pengertian dari data primair, sekunder, dan tersier. Juga ditemukan kalimat semacam ini , “...data tersier adalah kamus, majalah, buku-buku",2. Format standar yang telah menjadi fosil (fosiled) digunakan dalam karya penulisan ilmiah akhir penstudi ilmu hukum tersebut menunjukkan adanya kemandegan (stagnasi) dalam praktik metode penelitian hukum di Indonesia pada umumnya. Banyak dijumpai dalam karya mahasiswa hukum, teks peraturan perundang-undangan atau kebijakan, dimasukkan begitu saja untuk memenuhi ketebalan sebuah karya ilmiah. Dalam bagian itu, tidak ada penjelasan memadai dan tujuan analisis yang jelas, untuk tujuan apa dimuat dokumen hukum, atau pasal-pasal peraturan perundang-

\footnotetext{
${ }^{1}$ Lihat dalam Irianto, Sulistyowati \& Shidarta (eds), 2011, "Metode Penelitian Hukum: Konstelasi \& Refleksi". Jakarta: Yayasan Obor Indonesia

${ }^{2}$ Meskipun secara literer pengertian data tersier adalah benar demikian, namun perlukah penggunaan buku majalah, kamus, dikategrikan dan dilaporkan sebagai data ? Bukankah sudah pasti seluruh proses penulisan ilmiah merupakan proses dialektikan antara teori dan data, yang sudah pasti menggunakan berbagai sumber bacaan, dan tidak perlu lagi menyebutkan sumberbacaan tersebut sebagai sumber data. Hal yang harus dilakukan tentulah menggunakannya dan menyebutkan referensinya menurut kelaziman tradisi ilmiah.
} 
undangan tertentu. Karya-karya penelitian ilmu hukum tersebut menjadi sangat kering dan sumir meskipun sangat tebal sajian fisiknya. Demikian pula sekiranya ada putusan pengadilan yang dijadikan sebagai data, maka bahan tersebut disalin begitu saja, seringkali tidak ada analisis yang memadai yang memperlihatkan bahwa kasus hukum tersebut dibedah sedemikian rupa, direkonstruksi sehingga jelas duduk perkaranya, terkait dengan masalah penelitian yang dirumuskan, dan apa proses pembelajaran dari pertimbangan dan putusan hakim dari suatu kasus.

Demikian pula, penelitian adalah suatu bangunan logika, yang dari awal sampai akhir harus merupakan rangkaian yang saling menjelaskan satu sama lain. Harus ada suatu kesatuan alur dari awal sampai akhir. Kesatuan alur itu bersumber dari thesis yang dibuat, yang menjadi tulang punggung dari keseluruhan penelitian. Suatu penelitian dengan menggunakan langkah-langkah dan tahapan ilmiah yang sistematis, logis dan rasional, menjadikan seluruh proses penulisan ilmiah sebagai suatu penjelasan logika pemikiran yang merupakan proses dialektikan antara teori dan data.

Ada banyak model yang dikenal dalam kajian tentang hukum sebagai obyek telaahnya. Dari berbagai metode kajian hukum diantaranya di kenal metode pendekatan normatif yang mendasarkan diri pada logika dan teknik hukum. Pada sisi lain, pengkajian ilmu hukum dikenal pula metode pendekatan empirik, yang termasuk di dalamnya adalah model yurisprudensi (jurisprudence model) dan model sosiologis (sociological model) dengan menggunakan ilmu-ilmu sosial pijakannya.

Dari model pendekatan penelitian ilmu hukum tersebut, diantaranya diperlukan berbagai instrumen penelitian yang digunakan untuk mengumpulkan data dan bahan-bahan hukum. Salah satu instrumen untuk mengumpulkan data dan bahan-bahan hukum adalah metode survey. Seringkali penstudi maupun peneliti dibidang ilmu hukum melihat survey sebagai sarana untuk mengumpulkan data dari nara sumber atau informan penelitian untuk melakukan pengamatan dan wawancara pada pendekatan empiris (penelitian hukum non doktrinal). Pemahaman tersebut sesungguhnya merupakan bentuk penyederhanaan metode survey yang sesungguhnya merupakan instrumen peneltian yang bersifat kompleks dan komprehensif.

Bagi peneliti yang profesional, metode penelitian survey sesungguhnya merupakan suatu bentuk aktifitas yang sudah menjadi kebiasaan pada masyarakat ilmiah. Survey riset dikembangkan sebagai bentuk pendekatan positivis pada ilmu-ilmu sosial. Penelitian survey menanyakan kepada beberapa responden tentang kepercayaannya, pendapat-pendapat, 
karakteristik, dan perilaku yang telah atau sedang terjadi. Metode survey menyediakan pertanyaan-pertanyaan untuk penelitian tentang laporan keyakinan/kepercayaan atau perilaku diri. Pertanyaan-pertanyaan tersebut menjadi lebih tajam ketika responden memberikan jawaban-jawaban atas suatu pertanyaan-pertanyaan dengan variabel-variabel yang dikehendaki ${ }^{3}$.

Berangkat dari latar belakang permasalahan tersebut di atas, maka artikel "Hukum Dan Studi Penelitian Empiris: Penggunaan Metode Survey sebagai Instrumen Penelitian Hukum Empiris" ini hendak membahas dan mendeskripsikan tentang berbagai hal mengenai metode survey bagi kepentingan penelitian dalam ilmu hukum dengan berpijak pada beberapa pertanyaan sebagai bentuk permasalahan, yaitu tentang apa yang dimaksud dengan peneltian survey, apa tujuan, fungsi dan manfaat/kegunaan metode survey bagi penelitian ilmiah, bagaimana desain penelitian survey, serta bagaimana langkah-langkah pelaksanaan survey yang baik dan benar untuk memperoleh hasil penelitian sebagaimana diharapkan oleh peneliti.

\section{B. Pembahasan}

\section{Pengertian Penelitian Survey}

Penelitian survei merupakan suatu bentuk aktifitas yang sudah menjadi kebiasaan pada masyarakat, dan banyak diantaranya berpengalaman dengan riset ini sebagai suatu bentuk yang tersendiri atau yang lainnya. Survey riset dikembangkan sebagai bentuk pendekatan positivist pada ilmu-ilmu sosial. Sebagaimana dikatakan oleh Robert Groves, seorang ahli survey terkemuka, "survey menghasilkan informasi yang secara alami bersifat statistik". Survey merupakan bentuk dasar kuantitatif". Penelitian survey menanyakan kepada beberapa responden tentang kepercayaannya, pendapat-pendapat, karakteristik, dan perilaku yang telah atau sedang terjadi ${ }^{4}$.

Survey menyediakan pertanyaan-pertanyaan untuk penelitian tentang laporan keyakinan/kepercayaan atau perilaku diri. Pertanyaan-pertanyaan tersebut menjadi lebih tajam ketika responden memberikan jawaban-jawaban atas suatu pertanyaan-pertanyaan dengan variabel-variabel yang dikehendaki. Pada waktu melakukan survey biasanya peneliti menanyakan tentang beberapa hal, antara lain : ukuran beberapa variabel (seringkali dengan berbagai indikator), dan beberapa uji hipotesis dalam suatu survey tunggal. Meskipun suatu

\footnotetext{
${ }^{3}$ Robert Groves, seorang ahli survey terkemuka, "survey menghasilkan informasi yang secara alami bersifat statistik". Survey merupakan bentuk dasar kuantitatif” dalam Robert M. Groves, Survey Methodology (2010), Second edition of the (2004) first edition ISBN 0-471-48348-6

${ }^{4}$ Robert M. Groves, Survey Methodology (2010), Op.cit., halaman 57
} 
kategori bersifat tumpang tindih, beberapa pertanyaan dapat disertakan pada suatu survey, yaitu berkenaan dengan : 1) perilaku; 2) sikap, pendapat, keyakinan/kepercayaan; 3) karakteristik; 4) ekspektasi; 5) pengklasifikasian, dan 6) pengetahuan. Penelitian survey, titik beratnya diletakkan pada penelitian relasional; yakni mempelajari hubungan variabel-variabel, sehingga - secara langsung atau tidak langsung- hipotesa penelitian senantiasa dipertanyakan ${ }^{5}$.

Para sarjana melakukan survey dengan menggunakan sandaran pertanyaan pada tekanan kalimat "mengapa". Pertanyaan-pertanyaan "mengapa" adalah ukuran, jika peneliti ingin menemukan pemahaman subyektif responden atau teori informal. Karena beberapa responden dengan penuh kesadaran mengetahui faktor-faktor kausal yang membentuk perilaku atau keyakinan mereka, karena itu pertanyaan-pertanyaan tidak dapat diganti oleh peneliti dalam mengembangkan sebuah teori kausal yang konsisten dalam membangun literatur ilmiah.

Dalam survey, informasi dikumpulkan dari responden dengan menggunakan kuesioner. Umumnya penelitian survey dibatasi pada penelitian yang datanya dikumpulkan dari sampel atas populasi untuk mewakili seluruh populasi. Hal ini berbeda dengan sensus yang informasinya dikumpulkan dari seluruh populasi. Pada umumnya yang merupakan unit analisa dalam penelitian survey adalah individu. Penelitian survey dengan demikian adalah penelitian yang mengambil sampel dari satu populasi dan menggunakan kuesioner sebagai alat pengumpulan data yang pokok.

Untuk penelitian tertentu, unit analisa mungkin pasangan suami isteri, pasangan yang sudah bercerai atau rumah tangga sebagai keseluruhan tetapi satu wawancara tetap ditujukan kepada satu orang. Unit analisa ini perlu diperhatikan, terutama bagi peneliti pemula. Apabila peneliti tertarik untuk meneliti pola perkawinan dan perceraian pada tiga masyarakat melalui penelitian survey, maka yang perlu diingat bahwa unit analisanya adalah individu dan bukan masyarakat. Meskipun akhirnya memang diadakan perbandingan diantara ketiga masyarakat yang ditelitinya tersebut, berdasarkan data yang dianalisis dari jawaban-jawaban pertanyaan dari individu yang diteliti.

Penelitian survey dapat digunakan untuk : 1) penjajagan (eksploratif); 2) deskriptif; 3) penjelasan (explanatory atau confirmatory), yaitu menjelaskan hubungan kausal dan pengujian hipotesa; 4) evaluasi; 5) prediksi atau meramalkan kejadian tertentu di masa yang akan datang; 6) penelitian operasional, dan 7) pengembangan indikator-indikator sosial ${ }^{6}$.

\footnotetext{
${ }^{5}$ Singarimbun, Masri, Sofian Effendi (1989), Metode Penelitian Survai, LP3ES, Jakarta, halaman 98

${ }^{6}$ Singarimbun, Masri, Sofian Effendi (1989), loc.cit,
} 
Penelitian penjajagan atau ekploratif bersifat terbuka, masih mencari-cari. Pengetahuan peneliti tentang masalah yang akan diteliti masih terlalu tipis untuk melakukan studi deskkriptif. Suatu penelitian eksploratif dalam menggali pertanyaan-pertanyaan kepada responden masih belum memperoleh jawaban-jawaban yang jelas dan terperinci. Pada penelitian deskriptif, dimaksudkan untuk melakukan pengukuran yang cermat terhadap fenomena sosial tertentu. Peneliti mengembangkan konsep dan menghimpun fakta, tetapi tidak melakukan pengujian hipotesa. Suatu penelitian yang berusaha menjelaskan hubungan kausal antara variabel-variabel melalui pengujian hipotesa dinamakan penelitian pengujian hipotesa atau penelitian penjelasan (explanatory research). Perbedaan pokok antara penelitian deskriptif dan penelitian penjelasan (explanatory research) tidak pada sifat datanya, tetapi pada sifat analisanya ${ }^{7}$.

Penelitian survey juga dimanfaatkan untuk melakukan evaluasi. Di sini yang menjadi perhatian utama adalah pertanyaan pokok : seberapa jauh tujuan yang digariskan pada awal program tercapai atau mempunyai tanda-tanda akan tercapai. Hasil survey juga dapat digunakan untuk mengadakan prediksi mengenai suatu fenomena sosial tertentu. Di Amerika Serikat, poll adalah survey sampel yang menyangkut pendapat umum mengenai keadaan sosial politik. Ada kalanya hasil survey juga digunakan untuk mengadakan proyeksi penduduk. Dalam beberapa waktu ini penelitian survey juga banyak digunakan untuk penelitian operasional (operations research), dengan pusat perhatiannya adalah variabel-variabel yang berkaitan dengan aspek operasional suatu program. Setelah diidentifikasi hambatan-hambatan operasonalnya, penelitian dilakukan untuk mengatasi hambatan-hambatan tersebut.

\section{Disain Penelitian Survey}

Karakter survey analisis data tidak hanya mengandalkan pada tujuan dari studideskriptif atau ekplanatori- tetapi juga pada bentuk dari kemanfaatan disain. Betuk dasar pada desian penelitian survey adalah : desain pembagian silang (cross sectional design), studi kecenderungan (trend studies), panel studi (panel studies) dan sosiometrik (sociometric), dan desain kontekstual (contextual design).

Pada umumnya desain survey lebih banyak digunakan pada desain pembatasan silang (cross sectional design), dalam hal ini data dalam bagian silang (cross section) pada pilihan responden mewakili populasi amat besar yang mengumpulkan perhatian pada hal-hal yang perlu pada suatu waktu. Dengan "suatu hal pokok pada suatu waktu" tidak berarti bahwa responden telah diwawancarai atau dilakukan pengadministrasian kuesioner diri yang

\footnotetext{
${ }^{7}$ Sprent, P., Metode Statistik Nonparametrik Terapan, 1991, UI Press, Jakarta, halaman 127
} 
dikumpulkan secara berkelanjutan (meskipun kuesioner sedang dipelajari). Bagaimanapun juga data yang dikumpulkan pada jangka pendek adalah feasible. Banyak penelitian menyebutkan sebagai cross sectional desain. Tren studi dan panel studi adalah dua tipe dari desain longitudinal, yaitu suatu desain yang datanya dikumpulkan pada periode yang telah lampau.

\section{Unsur-unsur Penelitian Survey}

Sebagai suatu metode penelitian ilmiah, penelitian survey memiliki dasar pemikiran, prosedur, dan teknik-teknik khusus yang membedakannya dari metode lainnya. Penelitian survey terdiri dua tahap, yaitu proses teorisasi dan proses empirisasi. Untuk dapat melakukan proses-proses penelitian tersebut dengan baik, peneliti perlu memiliki pengetahuan yang baik tentang berbagai unsur penelitian. Pemahaman ini diperlukan pada proses teorisasi, karena dengan adanya pemahaman tentang konsep, proposisi, dan teori, peneliti akan dapat merumuskan hubungan-hubungan teoretis secara baik. Pada tahap empirisasi pengetahuan tentang variabel, hipotesa dan definisi operasional juga diperlukan aagar peneliti mempunyai gambaran yang jelas tentang data yang akan dikumpulkan dalam suatu penelitian.

\section{a. Konsep}

Dalam penelitian, seorang peneliti menggunakan istilah khusus untuk menggambarkan secara tepat fenomena yang hendak ditelitinya. Inilah yang disebut dengan konsep, yaitu, istilah dan definisi yang digunakan untuk menggambarkan secara abstrak : kejiadan, keadaan, kelompok atau individu yang menjadi pusat perhatian ilmu sosial. Melalui konsep, peneliti diharapkan akan dapat menyederhanakan pemikirannya dengan menggunakan satu istilah untuk beberapa kejadian (events) yang barkaitan satu dengan lainnya.

Dalam penelitian akan dijumpai dua jenis konsep. Pertama, konsep-konsep yang jelas hubungannya dengan fakta atau realitas. Kedua, konsep-konsep yang lebih abstrak atau kabur hubungannya dengan fakta atau realitas. Konsep-konsep yang tingkat abstraksinya lebih tinggi dari kejadian-kejadian konkrit merupakan inferensi. Sehingga tdak mudah menghubungkannya dengan kejadian, obyek, atau individu tertentu. Konsep yang abstrak ini seringkali disebut sebagai konstruks (constructs), karena dikonstruksikan dari konsep yang lebih rendah tingkat abstraksinya.

Konsep adalah abstraksi mengenai suatu fenomena yang dirumuskan atas dasar generalisasi dari sejumlah karakteristik kejadian, keadaan, kelompok atau individu tertentu. Peranan konsep dalam penelitian adalah menghubungkan teori oservasi, antara abstraksi dengan dan realitas. 


\section{b. Proposisi}

Dalam ilmu sosial, realitas sosial biasanya diabstraksikan sebagai hubungan antara dua konsep. Hubungan yang logis antara dua konsep disebut proposisi. Untuk analisa sederhana suatu realitas sosial dapat digambarkan sebagai satu proposisi. Untuk analisa yang lebih kompleks realitas sosial sering digambarkan sebagai beberapa hubungan antar konsep atau proposisi.

Proposisi tidak mempunyai format yang tertentu. Biasanya disajikan dalam bentuk suatu kalimat pernyataan yang menunjukkan hubungan antara dua konsep. Dalam penelitian sosial dikenal dua tipe proposisi, yaitu : aksioma atau postulat, dan teorem. Aksioma atau postulat adalah proposisi yang kebenarannya tidak dipertanyakan lagi oleh peneliti, sehingga tidak perlu diuji dalam suatu penelitian. Teorem adalah proposisi yang dideduksikan dari aksioma.

Proposisi yang kebenarannya tidak dipertanyakan lagi dalam penelitian sosial sangat jarang terjadi. Pada penelitian sosial, yang sering ditemui adalah aksioma-kasioma yang lebih lemah, yang penetapannya didasarkan pada asumsi mengenai ada atau tidaknya hubungan kausalitas antarkonsep yang yang dikandung ole aksioma tersebut.

c. Teori

Unsur penelitian yang mempunyai peranan utama adalah teori, karena dengan unsur ini peneliti mencoba meneranhgkan fenomena sosial atau fenomena alami yang menjadi pusat perhatian penlitian ilmiah. Teori merupakan serangkaian asumsi, konsep, konstruks, definisi, dan proposisi untuk menerangkan suatu fenomena sosial secara sistematis dengan cara merumuskan hubungan antar konsep.

Formulasi teori yang biasa digunakan adalah terdiri dari beberapa proposisi seperti dalil (lawlike) yang saling berhubungan satu dengan yang lain. Dalam perumusan teori seperti ini, peneliti ada proposisi yang dianggap sebagai aksioma, sehinggatidak perlu diuji kebenarannya. Atas dasar aksioma-aksioma itu peneliti merumuskan teorem-teorem yang dipandang dapt mengungkapkan fenomena sosial yang menarik perhaitan peneliti. Perumusan teori seperti ini disebut perumusan teori aksiomatis.

\section{d. Variabel}

Agar konsep-konsep dapat diteliti secara empiris, mereka dioperasionalisasikan dengan mengubahnya menjadi variabel, yang berarti sesuatu yang mempunyai variasi nilai. Caranya adalah dengan memilih dimensi tertentu pada konsep yang mempunyai vqariasi nilai. Dalam penelitian sosial, dikenal dua bentuk variabel, yaitu variabel kategorikal (categorical variable) 
dan variabel berkesinambungan (continuous variable). Variabel kategorikal adalah variabel yag membagi responden menjadi dua kategori atau beberapa kategori. Variabel yang terdiri dari dua kategori disebut variabel dikotomi(contohnya : jenis kelamin (pria/ wanita), status pekerjaan (bekerja/tidak bekerja), status perkawinan (kawin/tidak kawin), sedangkan variabel yang memiliki banyak variabel disebut variabel politomi (tidak sekolah, TK, SD, SMP, SMA, $\mathrm{S} 1, \mathrm{~S} 2, \mathrm{~S} 3)$.

Variabel berkesinambungan adalah variabel yang nilai-nilainya merupakan suatu skala, baik bersifat ordinal maupun rasio. Beberapa contoh variable ini dalam penelitian adalah : umur, jumlah pendapatan, jumlah pengeluaran rumah tangga, dan sebagainya). Dalam analisa seringkali variabel-variabel berkesinambungan diubah menjadi variabel kategorikal, agar peneliti dapat melakukan analisa-analisa kategorikal seperti tabulasi silang dan analisa varians. Sebaliknya variabel kategorikal tidak dapat langsung diubah menjadi variael berkesinambungan.

\section{e. Hipotesa.}

Hipotesa adalah sarana penting penelitian yang tidak dapat ditinggalkan, ia merupakan instrumen kerja dari teori. Sebagai hasil deduksi dari teori atau proposisi, hipotesa lebih spesifik sifatnya, sehingga lebih siap untuk diuji secara empiris. Dalam penelitian, suatu proposisi harus dijabarkan menjadi hipotesa yang lebih terinci. Proposisi yang dijabarkan menjadi hipotesa menjadi lebih operasional, lebih siap untuk diuji secara empiris, karena variabel-variabelnya dapat diukur.

Suatu hipotesa selalu dirumuskan dalam bentuk pernyataan yang menghubungkan antara dua variabel atau lebih. Hubungan tersebut dapat dirumuskan secara eksplisit maupun secara implisit. Dalam penelitian sosial yang sebenarnya, jarang sekali ditemukan suatu fenomena yang dapat diabstraksikan sebagai hipotesa yang terdiri dari dua variabel. Masalah sosial selalu merupakan interaksi antara banyak variabel, sehingga merupakan suatu hubungan yang multivarian ${ }^{8}$.

Sebagian peneliti sosial berpendapat bahwa hipotesa tidak selalu diperlukan dalam suatu penelitan, karena kebebasan peneliti menjadi terganggu. Pendapat ini muncul karena adanya kekhawatiran bahwa peneliti cenderung untuk mencari data yang dapat membenarkan hipotesa mereka, dan hanya menguji hubungan yang sudah jelas saja. Pendapat seperti ini tidak

${ }^{8}$ Groves, R., Wissoker, D., Greene, L., McNeeley, M., and Montemarano, D. (2000), "Common Influences on Noncontact Nonresponse Across Household Surveys: Theory and Data," paper presented at the annual meetings of the American Association for Public Opinion Research., halaman 48 
sepenuhnya benar, karena dengan demikian fungsi hipotesa telah ditafsirkan secara salah. Hal seperti ini jelas suatu tindakan yang salah, karena hipotesa yang tidak terbukti mempunyai nilai ilmiah yang sama pentingnya. Hipotesa yang tidak terbutki akan menghasilkan pemikiranpemikiran yang baru, baik berupa teori baru amupun metodolagi baru, yang akan terus menerus akan memberikan kontribusi bagi pengembangan ilmu pengetahuan ${ }^{9}$.

Teori dan hipotesa adalah seperangkat ilmu yang diperlukan peneliti untuk membuktikan kebenaran dengan cara menerangkan fenomena sosial melalui suatu pengujian secara terkontrol. Dengan demikian salah satu langkah penting dalam penelitian adalah merumuskan hipotesa yang variabel-variabelnya dapat diukur, sehingga pengujian hipotesa dapat dilakukan secara baik dan sistematis. Selain mencoba untuk menerangkan hubunganhubungan untuk menggambarkan suatu fenomena sosial, hipotesa juga merupakan suatu prediksi yang dapat diuji secara empiris.

\section{f. Definisi Operasional}

Konsep-konsep sosial yang sudah diterjemahkan menjadi satuan yang lebih operasional, yaitu variabel dan konstruk (construct), biasanya belum sepenuhnya siap untuk dilakukan pengukuran. Hal demikian ini karena variabel dan konstruk sosial mempunyai beberapa dimensi yang dapat diukur secara berbeda. Definisi operasional adalah unsur penelitian yang memeritahukan bagaimana cara mengukur suatu variabel. Dengan kata lain definisi operasional adalah suatu informasi ilmiah yang sangat membantu peneliti lain yang ingin mengunakan variabel yang sama.

Dari informasi tersebut peneliti dapat mengetahui bagaimana caranya pengukuran suatu variabel dapat dilakukan. Dengan demikian seorang peneliti dapat menentukan apakah prosedur pengukuran yang sama akan dilakukan atau diperlukan prosedur pengukuran yang baru.

\section{Langkah-langkah Pelaksanaan Survey}

Peneliti survey dalam melaksanakan survey mengikuti pendekatan deduktif . Peneliti memulai dengan sebuah teorisasi atau menerapkan masalah penelitian dan diakhiri dengan ukuran empiris dan analisis data. Sedikitnya sekali, seorang peneliti menentukan bahwa suatu survey adalah metode yang tepat, adapun langkah dasar pada suatu proyek penelitian dapat ditentukan ke dalam subbagian gagasan utama pada figur 1.

\footnotetext{
${ }^{9}$ Loc.cit.
} 


\section{Bagan Ragaan 1. A Survey from a Process Perspective}

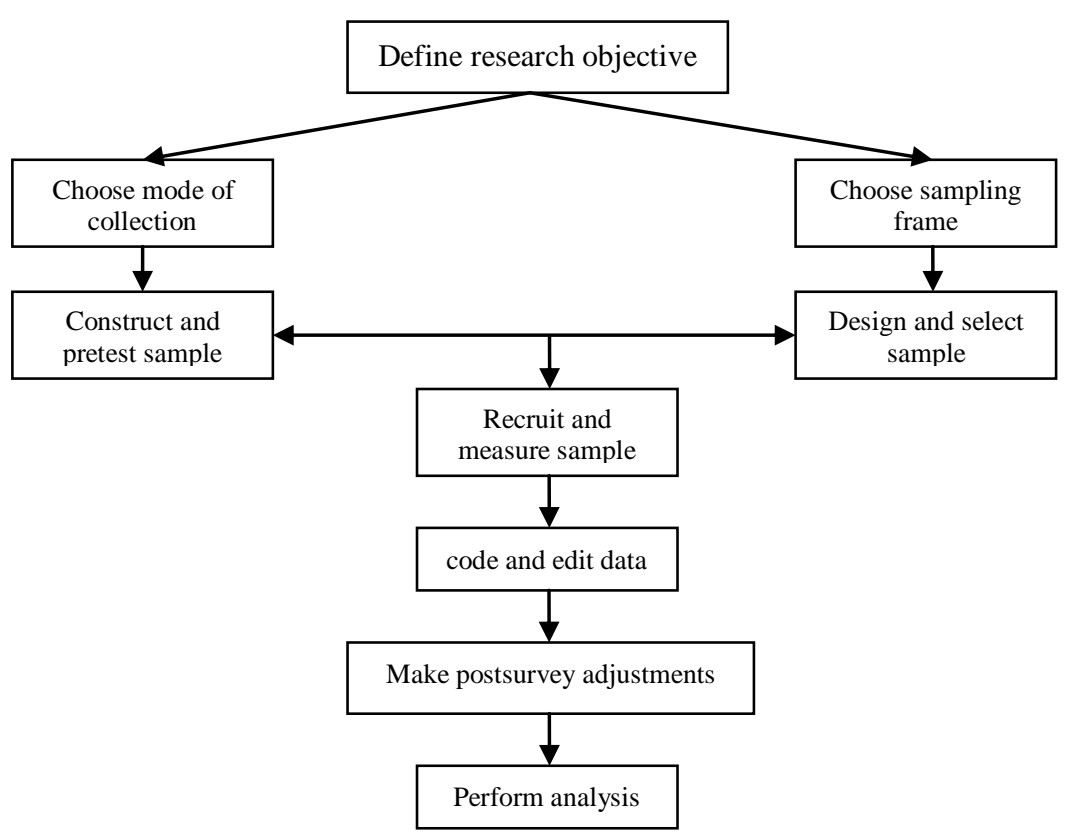

Sumber: Groves, Robert M., Survey Methodology (2010),

Second edition of the (2004) first edition ISBN 0-471-48348-6

Pada tahap pertama, peneliti membangun sebuah instrumen-sebuah pertanyaan survey atau daftar pertanyaan- yang akan digunakan peneliti untuk mengukur variabel-variabelnya. Responden membaca dan menjawab dengan memberi tanda pada kuesioner tersebut. Sebuah jadual interview adalah seperangkat pertanyaan dari petugas interview yang ditujukan kepada responden, yang juga merupakan catatan atas tanggapan responden.

Peneliti menyusun konsep dan mengoperasionalkan variabel-variabel suatu pertanyaan. Peneliti mencatat dan mengulangi pertanyaan untuk mengklarifikasi dan melengkapi data yang diperoleh dari wawancara tersebut, dan mengorganisasi pertanyaan-pertanyaan ke dalam pokok-pokok kuesioner pada pertanyaan penelitian, responden dan bentuk-bentuk survey.

Pada saat mempersiapkan kuesioner, peneliti harus memikirkan bagaimana dia akan mencatat dan mengelola data-data yang akan dianalisis. Peneliti memandu pengujian dengan seperangkat kuesioner ke responden yang sama pada akhir survey. Jika mengunakan petugas interview, maka peneliti perlu melatih mereka tentang bahan-bahan kuesioner. Petugas interview mewawancarai responden dengan jelas sesuai pertanyaan yang disebutkan dalam 
panduan pengujian dan menggali secermat mungkin yang dipahami oleh responden. Pada tahap ini peneliti juga perlu memberikan gambaran diantara dengan beberapa contoh konkrit ${ }^{10}$.

Setelah tahap perencanaan, peneliti siap untuk mengumpulkan data. Kemudian dilanjutkan dengan tahap penyortiran data. Peneliti menempatkan sampel responden secara tersendiri, melalui telepon, atau surat. Responden menerima informasi atau petunjuk pada kuesioner atau inerview. Pertanyaan disertakan, dan dengan pola memberi berupa dorongan/ tanggapan atau pertanyaan/jawaban. Peneliti dengan cermat mencatat jawaban atau tanggapan dengan segera setelah responden memberi jawaban. Setelah repsonden melengkapi semua kuesioner dan peneliti menerimanya, peneliti mengelola data dan menyiapkannya untuk dilakukan analisis statistik.

\section{Sesimpulan}

Konklusi hasil penelitian ini adalah sebagai berikut: Pertama, Dalam studi ilmu hukum, penelitian adalah suatu bangunan logika, yang dari awal sampai akhir harus merupakan rangkaian yang saling menjelaskan satu sama lain; Kedua, Suatu penelitian hukum dengan menggunakan langkah-langkah dan tahapan ilmiah yang sistematis, logis dan rasional, menjadikan seluruh proses penulisan ilmiah sebagai suatu penjelasan logika pemikiran yang merupakan proses dialektikan antara teori dan data; Ketiga, Pada penelitian hukum, metode survey dimanfaatkan untuk melakukan eksplorasi dan evaluasi berbagai kebijakan dan keputusan, dan implikasi regulasi pada masyarakat. Hasil survey juga dapat digunakan untuk mengadakan prediksi mengenai suatu fenomena sosial tertentu, termasuk didalamnya adalah berlakunya hukum positif dalam konteks kehidupan sosial kemasyarakatan dan bernegara.

Rekomendasi pada penelitian ini adalah: Pada penelitian hukum yang menggunakan metode penelitian survey pada saat mempersiapkan kuesioner, peneliti harus memikirkan bagaimana dia akan mencatat dan mengelola data-data yang akan dianalisis; Peneliti memandu pengujian dengan seperangkat kuesioner ke responden yang sama pada akhir survey. Peneliti juga perlu melatih mereka tentang bahan-bahan kuesioner; Begitu pula pada saat petugas interview mewawancarai responden dengan jelas sesuai pertanyaan yang disebutkan dalam panduan pengujian dan menggali secermat mungkin yang dipahami oleh responden.

${ }^{10}$ Groves, R., Dillman, D., Eltinge, J., and Little, R. (eds.) (2002), Survey Nonresponse, New York: Wiley. 


\section{Kepustakaan}

Irianto, Sulistyowati \& Shidarta (eds), 2011, "Metode Penelitian Hukum: Konstelasi \& Refleksi”. Jakarta, Yayasan Obor Indonesia

Groves, R., Dillman, D., Eltinge, J., and Little, R. (eds.) (2002), Survey Nonresponse, New York: Wiley.

Groves, R., Wissoker, D., Greene, L., McNeeley, M., and Montemarano, D. (2000), "Common Influences on Noncontact Nonresponse Across Household Surveys: Theory and Data," paper presented at the annual meetings of the American Association for Public Opinion Research.

Groves, Robert M., Survey Methodology (2010), Second edition of the (2004) first edition ISBN 0-471-48348-6

Juster, F., and Smith, J. (1997), "Improving the Quality of Economic Data: Lessons from the HRS and AHEAD," Journal of the American Statistical Association, 92, pp. 1268-1278.

Singarimbun, Masri, Sofian Effendi (1989), Metode Penelitian Survai, LP3ES, Jakarta

Sprent, P., Metode Statistik Nonparametrik Terapan, 1991, UI Press, Jakarta

Van der Zouwen, J., Dijkstra, W., and Smit, J. (1991), "Studying Respondent Interviewer Interaction: The Relationship between Interviewing Style, Interviewer Behavior, and Response Behavior," in Biemer, P., Groves, R., Lyberg, L., Mathiowetz, N., and Sudman, S. (eds.), Measurement Errors in Surveys, pp. 419-438, New York: Wiley.

Vehovar, V., Batagelj, Z., Lozar Manfreda, K., and Zaletel, M. (2002), "Nomesponse in Web Surveys," in Groves, R., Dillman, D., Eltinge, J., and Little, R. (eds.), Survey Nonresponse, pp. 229-242, New York: Wiley. 